УДК 528.942: 551.577 .21

\title{
THE ANALYSIS OF RELATIONSHIPS BETWEEN ANNUAL PRECIPITATION AND RELIEF AND LANDSCAPE CHARACTERISTICS IN THE CARPATHIAN REGION OF UKRAINE
}

\author{
Oleksandr Mkrtchian, Pavlo Shuber \\ Ivan Franko National University of Lviv, \\ P. Doroshenko Str., 41, UA - 79000 Lviv, Ukraine, \\ e-mail: alemkrt@gmail.com
}

The paper deals with the statistical analysis of relationships between the spatial distribution of precipitation values in the Carpathian region of Ukraine and the spatially distributed relief and landscape parameters. Processed data of 20 weather stations have been a data source of annual precipitation data for 1961-1991 period, while SRTM elevation dataset has been used as a source of spatial data on relief parameters. Step-wise multiple regression has revealed the set of parameters manifesting the strongest relationship with the precipitation distribution. This set includes following parameters: terrain roughness, local and focal elevation, and aspect factor for NW/SE direction; the overall relationship is highly statistically significant. The terrain roughness has appeared to be the single parameter with the strongest effect on precipitation values, followed by the local and focal elevation and the aspect factor.

ANOVA results were much more modest in comparison with the multiple regression, suggesting that the quantitative spatial modeling, which uses relief parameters as predictors, produces much more reliable predictions of the precipitation spatial distribution than just averaging the precipitation values round the delineated natural regions. ANCOVA results show that the interaction between the quantitative and numerical predictors is statistically significant with the p-value of less than 0.01 , suggesting that belonging to natural regions can moderate the impact of quantitative relief parameters. Thus considering the belonging to natural regions significantly improves the final prediction, when used in addition to numerical relief parameters.

Key words: annual precipitation, climatic mapping, multiple regression, ANOVA, AVCOVA.

The precipitation amount is one of the most important climatic characteristics that determines the water balance of the region, influences soil water regime, the character of vegetation, the conditions for agriculture and some other human activities. Thus, the detailed and reliable information on precipitation distribution is important for the planning and regulation of agriculture, forestry, tourism, nature conservation, in hydraulic engineering, irrigation and drainage, as well as for the hydrological, soil, and ecological studies.

Data on precipitation regime, like the most of other climatic parameters, are obtained primarily on point locations where rain gauges and other meteorological appliances are stationed. This leads to the problem of the data interpolation, as the actual values for locations between neighboring gauges separated by a distance of tens of $\mathrm{km}$ could be sufficiently different. At the advent of modern geoinformation technologies this problem can now be solved using formal scientifically and statistically grounded techniques, instead of more traditional manual and haphazard approaches, thus sufficiently increasing the accuracy and reliability of obtained maps and spatial datasets.

(C) Mkrtchian O., Shuber P., 2015 
The mapping of precipitation values, as well as other climatic characteristics, could be greatly facilitated by using auxiliary data that is closely related to the specified characteristic and has a sufficiently detailed continuous spatial coverage. The good example of such a data is terrain characteristics that are closely related to climate and that can be represented by Digital Elevation Models (DEM) and their derivative parameters. There are several sources of DEM data produced by satellite imaging, probably the most widely used of which is Shuttle Radar Topographic Mission (SRTM) [7]. Recently a new version of this data has been released: a 1-arc second global elevation coverage (roughly equivalent to 30 meters), covering most parts of the world, while earlier versions have a three arc second $(\sim 90 \mathrm{~m})$ resolution. The spatial resolution of tens of meters is fully enough for the modeling of the factors that influence the mesoclimatic regime and for making the maps based on the interpolation of data obtained by the regular observations on weather stations and stationary rain gauges. The more spatially detailed modeling and mapping would require another data sources and types of modeling that take into account the various sources of microclimatic differentiation.

The land surface relief can be characterized by a set of quantitative parameters some of which have a more or less pronounced impact on the climatic characteristics, mainly through the redistribution of the incoming solar energy, the alteration of air masses movements, and the increase in air turbulence that affects the cloud and precipitation formation. The elicitation of such parameters and the analysis of their impact on the climatic characteristics can assist in the creation of more precise and reliable climatic maps, obtaining more reliable climatic references for the important locations like resorts, airports, solar and wind power stations. The theoretical inferences could also be made regarding the structure and dynamics of climatic fields, the relationships between different components and elements of geoecosystems and natural environment.

Another interesting theoretical question regards the inherent structure of the climatic variability. Namely, whether it mainly follows a continuous gradient of relief parameters like elevation, or the sharp spatial changes associated e.g. with the boundaries of the natural regions also playing an important role.

Up until present, taking into account the relief parameters in the climatic mapping has been restricted to a one or a few (generally only absolute elevation was considered) and their impact has often been modeled by a subjective approaches and methodologies. For example, the climatic differentiation in the Ukrainian Carpathians is traditionally described through a set of bioclimatic belts. Each one of these belts corresponds to a certain range of absolute elevations (somewhat different on the North-Eastern and South-Western macroslopes) and is considered to be characterized by a certain span of major climatic parameters, like the average summer and winter temperatures, sums of biologically active temperatures, precipitation amounts, etc [5].

It is well known that in the mountains the elevation is an important parameter connected to the spatial changes in the many climatic characteristics. In the temperate zone the rise in elevation is usually accompanied by the decreases in temperatures and their annual and diurnal ranges, the decrease in the duration of the vegetative period, and the increase in precipitation amount. Yet some other relief parameters like the terrain aspect and ruggedness can also have a significant impact on climate characteristics and thus can be effectively used for their modeling and mapping, as was shown in our previous studies [3, 4]. 
Recently a group of researchers aimed at the creation of a high-resolution $(1 \times 1 \mathrm{~km})$ monthly temperature dataset for the Greater Alpine region has analysed the impact of a number of relief, geographic and landscape characteristics, using multilinear regression techniques and regionalization. The elevation appeared to be the single variable that has the strongest influence among all, explaining $69 \%$ of temperature variance averaged over the year, reaching the maximum explained value in May $(85 \%)$ and minimum in January $(45 \%)$. Vertical lapse rate has a similar seasonal pattern, reaching maximum in May $\left(-0.62{ }^{\circ} \mathrm{C} / 100 \mathrm{~m}\right)$ and minimum in January $\left(-0.42{ }^{\circ} \mathrm{C} / 100 \mathrm{~m}\right)$. Differences in latitude explained $19 \%$ of temperature variance over all months, reaching minimum in May (only $10 \%)$. The longitudinal effects appeared to be negligible, explaining only $1 \%$ of the temperature variance averaged over the year [8].

The distances from the coast capture maritime influences and account for $41 \%$ of the variation of the temperature normals, with maximum - 52\% - in January, and minimum $27 \%$ - in May (respective temperature decreases per 100 topographically weighted $\mathrm{km}$ from the coast $-1.02{ }^{\circ} \mathrm{C}$ and $0.78^{\circ} \mathrm{C}$ ). Another landscape factor has been the effect of lakes: the warming effect has been typical for most lakes throughout the year. The big cities significantly increase temperatures in their vicinities: $1.6^{\circ} \mathrm{C}$ is a typical value for the strength of the heat island of million-strong cities, $0.4-0.8^{\circ} \mathrm{C}-$ for large cities. The cold air pool effect has been observed in narrow deep valleys, showing itself through temperature decreases [8].

The seminal summarizing work on the mountain climate and influencing factors is the book by R.G. Barry that has been first published in 1981 and in 2008 went through the $3^{\text {rd }}$ Edition [6].

The goal of the paper is to analyze how the averaged annual precipitation values measured in weather station in the Carpathian region of Ukraine are influenced by a number of relief parameters and also by their belonging to a set of natural regions.

The data used in the study were obtained by the processing of pluviometric observations made on the weather stations located in the Carpathian region of Ukraine. The 20 locations were used for each of which the continuous series of observations on precipitation exists for the period of yrs. 1961-1991. For each of these locations the average annual precipitation values have been calculated from the data derived from the official bulletin [2].

SRTM elevation dataset has been used as a source of relief data. The raw elevation data have been the basis for the calculation of the set of derivative numeric relief parameters, which has been accomplished through the raster GIS functions. These parameters included the terrain roughness, the surface aspect factor, and the surface curvature. Every derivative parameter has been recalculated for different moving window sizes, thus allowing accounting for the different spatial scales of impact of relief parameters on precipitation.

The natural regions boundaries have been derived from the map of physical-geographic regionalization from the National Atlas of Ukraine [1]. The regions of the rank "oblast" have been chosen on the scale and statistical considerations (at least a few data points should correspond to each of the category).

The multiple regression analysis has been used to assess the relationships between the precipitation values and the numeric relief parameters. The Analysis of variance (ANOVA) method has been used for assessing the impact of the belonging to natural regions on precipitation (a qualitative variable). To evaluate the combined impact of the mentioned numeric and qualitative variables, the Analysis of covariance (ANCOVA) method has been 
applied. Each of these methods allows calculating a set of statistical measures that characterize the significance, strength and direction of relationships.

The summary of the calculated measures of the relationships between the precipitation amounts and the numeric and qualitative parameters is given in table. The multiple regression method involved the procedure of the selection from the large set of terrain parameters a few of those, which together display the highest degree of the relationship with the precipitation values. The selection process also involved the search for the optimal size of the moving window for every relief parameter, and for the aspect parameter also the optimal direction of aspect (from 4 possible) which exhibits the strongest relationship with the precipitation distribution. The step-wise forward and backward regression has been used in the process, while looking for the best values of the produced statistical measures. As a result, four relief parameters have been selected, in the order of the strength and the reliability of the relationship: terrain roughness (calculated in $10 \mathrm{~km}$ moving window), local elevation, aspect factor for NW/SE direction (calculated in $10 \mathrm{~km}$ moving window), and focal elevation (calculated in $10 \mathrm{~km}$ moving window).

The overall relationship is highly significant, as well as every of the mentioned parameters. The appending of other parameters does not increase the strength and reliability of the model. The sign of the influence of the first two of the relief parameters is positive (the precipitation generally increases with the increase in terrain roughness and the local elevation), while the focal elevation relates to precipitation value with the negative sign.

The ANOVA results were much more modest in comparison with the multiple regression, as indicated by the appropriate statistical measures. It suggests that the quantitative spatial modeling, which uses relief parameters as predictors, produces much more reliable predictions of the precipitation spatial distribution than just averaging the precipitation values round the delineated natural regions.

The summary of the statistical analyses results

\begin{tabular}{|l|c|c|c|c|}
\hline $\begin{array}{c}\text { Statistical measure / } \\
\text { Method of analysis }\end{array}$ & $\mathbf{r}$ & $\mathbf{r}^{2}$ adjusted & $\mathbf{F}$ & $\begin{array}{c}\text { Standard prediction } \\
\text { error }\end{array}$ \\
\hline Multiple regression & 0.98 & 0.96 & 109.39 & 51.96 \\
\hline ANOVA & 0.91 & 0.76 & 13.27 & 123.32 \\
\hline ANCOVA & 0.995 & 0.98 & 120.62 & 28.55 \\
\hline
\end{tabular}

The ANCOVA results suggest that the belonging to natural regions can moderate the impact of quantitative relief parameters. All the ANCOVA effects were statistically significant, as indicated by the values of Wald statistic. Univariate results test shows that the interaction between the quantitative and numerical variables is significant with the p-value less than 0.01. Thus, while the belonging to natural regions is the poor predictor of the precipitation values by itself, it can complement and improve the predictions produced by the regression on numerical relief parameters, if additionally taken into account. While this effect is in our case rather marginal from the practical point of view, it is statistically significant.

The analysis of data has revealed that the precipitation values relate significantly to a number of morphometric relief parameters as well as to the position in the regional landscape structure. The terrain roughness has appeared to be the single parameter with the strongest effect on precipitation values, followed by the local and focal elevation and the aspect factor. The multiple regression with these four parameters as independent variables 
allows mapping the precipitation spatial distribution with a high precision and reliability. The ANOVA model that considers only the situation in a regional landscape structure as a qualitative predictor has given much poorer result, but using of this qualitative predictor as an complementary one it addition to numerical relief parameters in ANCOVA model significantly improves the final prediction.

\section{СПИСОК ВИКОРИСТАНОЇ ЛІТЕРАТУРИ}

1. Маринич О.М. Фізико-географічне районування (карта) / О. М. Маринич, Г. О. Пархоменко, В. М. Пащенко, О. М. Петренко, П. Г. Шищенко // Національний атлас України. - К. : Картографія, 2007. - С. 228-229.

2. Метеорологический ежемесячник. - К. - Вып. 10, № 1-12, 1961-1991.

3. Мкртчян О.С. Геоінформаційне моделювання температурного поля західних регіонів України / О. С. Мкртчян, П. М. Шубер // Фіз. географія і геоморфологія. 2009. - Вип. 57. - С.104-112.

4. Мкртчян О.С. Методика геопросторового моделювання та картування кліматичних характеристик за даними спостережень / О. С. Мкртчян, П. М. Шубер // Вісн. Львів. ун-ту. Сер. геогр. - 2011. - Вип. 39. - С. 245-253.

5. Природа Українських Карпат / за ред. К. І. Геренчука. - Львів : Вища шк., 1968. 267 c.

6. Barry R. G. Mountain Weather and Climate / R. G. Barry. - CUP Archive, 1981. $313 \mathrm{pp}$.

7. Farr T. G. The Shuttle Radar Topography Mission / T. G. Farr, P. A. Rosen, E. Caro, R. Crippen, R. Duren, S. Hensley, M. Kobrick, M. Paller, E. Rodriguez, L. Roth [et al.] // Reviews of Geophysics. - 2007. - N 45, RG2004.

8. Hiebl J. A high-resolution 1961-1990 monthly temperature climatology for the greater Alpine region / J. Hiebl, I. Auer, R. Bohm, W. Schoner, M. Maugeri, G. Lentini, J. Spinoni, M. Brunetti, T. Nanni, M. P. Tadic, Z. Bihari, M. Dolinar, G. MullerWestermeier // Meteorologische Zeitschrift. - 2009. - Vol. 18, N 5. - P. 507-530.

\section{REFERENCES}

1. Marynych, O. M., Parkhomenko, H. O., Pashchenko, V. M., Petrenko, O. M., \& Shyshchenko, P. H. (2007). Fizyko-heohrafichne raionuvannia (karta). Natsionalnyi atlas Ukrainy. Kyiv: Kartohrafiia, 228-229 (in Ukrainian).

2. Meteorologicheskij ezhemesjachnik, 10(1-12), Kiev, 1961-1991 (in Russian).

3. Mkrtchian, O. S., \& Shuber, P. M. (2009). Heoinformatsiine modeliuvannia temperaturnoho polia zakhidnykh rehioniv Ukrainy. Fizychna heohrafiia $i$ heomorfolohiia, 57, 104-112 (in Ukrainian).

4. Mkrtchian, O., \& Shuber, P. (2011). A method for geospatial modeling and mapping of climatic characteristics from meteostation observation data. Visnyk of the Lviv university. Series Geography, 39, 245-253 (in Ukrainian).

5. Herenchuk, K. I. (Ed.). (1968). Pryroda Ukrainskykh Karpat. Lviv: Vyshcha shkola, 267 pp. (in Ukrainian).

6. Barry, R. G. (1981). Mountain Weather and Climate. CUP Archive, 313 pp. 
7. Farr, T. G., Rosen, P. A., Caro, E., Crippen, R., Duren, R., Hensley, S., Kobrick, M., Paller, M., Rodriguez, E., Roth, L. et al. (2007). The Shuttle Radar Topography Mission. Reviews of Geophysics, 45.

8. Hiebl, J., Auer, I., Bohm, R., Schoner, W., Maugeri, M., Lentini, G., Spinoni, J., Brunetti, M., Nanni, T., Tadic, M. P., Bihari, Z., Dolinar, M., \& Muller-Westermeier, G. (2009). A high-resolution 1961-1990 monthly temperature climatology for the greater Alpine region. Meteorologische Zeitschrift, 18(5), 507-530.

Стаття: надійшла до редакиії 06.08.2015

доопрацььована 20.10.2015

прийнята до друку 17.11.2015

\title{
АНАЛІЗ ЗВ'ЯЗКУ МІЖ РІЧНИМИ СУМАМИ ОПАДІВ ТА ХАРАКТЕРИСТИКАМИ РЕЛЬЕФУ І ЛАНДШАФТНОЇ СТРУКТУРИ В КАРПАТСЬКОМУ РЕГІОНІ УКРАЇНИ
}

\author{
Олександр Мкртчян, Павло Шубер \\ Львівський національний університет імені Івана Франка, \\ вул. П. Дороченка, 41, 79000, м. Львів, Украӥна, \\ e-mail:alemkrt@gmail.com
}

Розглянуто статистичний аналіз зв'язків між просторовим розподілом річних сум опадів у Карпатському регіоні України та просторово розподіленими морфометричними параметрами i ландшафтною структурою. Джерелом даних щодо розподілу річних сум опадів за період 1961-1991 рр. слугували оброблені дані 20 метеостанцій, тоді як джерелом даних щодо морфометричних параметрів була цифрова модель рельєфу SRTM. Покрокова множинна регресія дала змогу виділити набір параметрів, які виявили найсильніший зв'язок із розподілом опадів. Цей набір охоплював такі параметри: розчленованість рельєфу, локальне й фокальне перевищення та фактор експозиції за румбом Пн-Зх-Пд-Сх; регресійна модель засвідчила високу статистичну значимість. Найсильніше на кількість опадів впливає розчленованість рельєфу, дещо слабше - перевищення та фактор експозиції.

Результати дисперсійного аналізу виявились суттєво скромнішими порівняно з регресійним, засвідчивши, що кількісне просторове моделювання, у якому використовують параметри рельєфу як предиктори, дає значно надійніші передбачення розподілу кількостей опадів порівняно $з$ простим усередненням цих кількостей за виділеними природними областями. Коваріаційний аналіз виявив, що взаємодія між якісними та кількісними предикторами $\epsilon$ статистично значимою ( $<0,01)$, доводячи, що належність до природних областей здатна модифікувати вплив на розподіл опадів кількісних морфометричних параметрів. Отже, додаткове врахування положення в ландшафтній структурі (належності до певної фізико-географічної області) статистично значимо поліпшує точність моделювання сум опадів.

Ключові слова: річні суми опадів, кліматичне картування, множинна регресія, дисперсійний аналіз, коваріаційний аналіз. 